Academic Platform Journal of Engineering and Science

\title{
Fren Balatası Üretimi için Zirkonya Esaslı Yeni Kompozisyonların Geliştirilmesi
}

\author{
*1 Arife Yurdakul, ${ }^{2}$ Nurdan Baştürk \\ ${ }^{1,2}$ Alanya Alaaddin Keykubat Üniversitesi, Rafet Kayış Mühendislik Fakültesi, Metalurji ve Malzeme Mühendisliği Bölümü, \\ Alanya, Antalya, Türkiye \\ *1arife.yurdakul@alanya.edu.tr, (D) 2basturknurdan@gmail.com,
}

Araștırma Makalesi

Geliş Tarihi: 05.09.2018

Kabul Tarihi: 29.01.2019

Öz

Bu çalışmada, fren balatası üretiminde günümüzde tercih edilen toksik esaslı malzeme bileşenlerinin yerine saflığı yüksek, düşük maliyetli ve en önemlisi insan sağlığı açısında zararlı olmayan tozları kullanmak amaçlanmıştır. Bu doğrultuda, fren balatası üretiminde genellikle dört veya beş bileşen olarak çoklu sayıda kullanılan hammaddelere alternatif olarak, üretimde içeriğe eklenecek tamamen seramik esaslı iki bileşenli yeni kompozit malzemeler geliştirilmiştir. Ayrıca, bu kompozit malzeme içeriği ile birlikte fren balatası ömrünün de uzatılması hedeflenmiştir. Kompozitin ana kompozisyonunu oluşturan başlangıç malzemesinde itriyum stabilize tetragonal zirkonya (Y-TZP) tozları matris faz olarak tercih edilmiştir. Y-TZP yüksek refrakterlik ve tokluk değerleri göstermesi sebebiyle kompozisyonun temel bileşimini oluşturmaktadır. Y-TZP içerisine belirli oranlarda alümina $\left(\mathrm{Al}_{2} \mathrm{O}_{3}\right)$ ve mangan oksit $(\mathrm{MnO})$ takviyesi yapılarak hazırlanan başlangıç bileşimlerinin soğuk izostatik preslenmesi (CIP) sonras $1500-1600^{\circ} \mathrm{C}$ 'de sinterlenmesi ile yı̆̆ınsal prototip numuneler üretilmiştir. Numunelerdeki faz ve mikroyapısal değişim ile birlikte fiziksel ve mekanik özellikler, sırasıyla X-1şını kırınımı (XRD), taramalı elektron mikroskobu (SEM) ve enerji saçınımlı X-ışını (EDX) spektroskopisi, Arşimet yoğunluk ölçümü, Vickers sertlik ve tokluk analizleri ile triboloji aşınma testleri uygulanarak tespit edilmiştir. Elde edilen sonuçlar birlikte değerlendirildiğinde, fren balata sistemlerinin üretiminde içeriğe eklenecek bir seramik kompozit örneğinin, seramik esaslı malzemelerden hazırlanarak yüksek mekanik özelliğe ve düşük aşınmaya sahip olabileceği mümkün görülmüştür. Böylece, bu çalışma ile fren balatalarının mevcut üretim teknolojileri üzerine farklı yeni bir yaklaşım sunulmuştur.

Anahtar Kelimeler: Fren balatas1, kompozit, mikroyap1, seramik, zirkonya (Y-TZP)

\section{The Development of Zirconia-Based New Formulations for Brake Pad Production}

\author{
*1 Arife Yurdakul, ${ }^{2}$ Nurdan Baştürk \\ ${ }^{1,2}$ Alanya Alaaddin Keykubat University, Rafet Kayış Faculty of Engineering, Department of Metallurgical and Materials \\ Engineering, Alanya, Antalya, Türkiye \\ *1arife.yurdakul@alanya.edu.tr, ${ }^{2}$ basturknurdan@gmail.com
}

\begin{abstract}
In present research, it was aimed to utilize high-purity, low-cost, and most importantly non-toxic powders for human health instead of their toxic-based material counterparts which are now preferred in brake pads production. For this purpose, ceramicbased two-component bearing new composite materials added to content in production were developed for common raw materials that consisted of generally four or five constituents used in the production of brake pad. In addition, it was also expected to extend the life span of brake pad by this composite material content. In the brake pad production, yttrium-stabilized tetragonal zirconia (Y-TZP) powders were preferred to matrix phase among the starting materials that forming the main composition of composite. Y-TZP was also considered as key component due to its high refractory and toughness properties. The bulk prototype samples were produced by cold isostatic pressing (CIP) and following the sintering at $1500-1600^{\circ} \mathrm{C}$ from starting formulations that composed of alumina $\left(\mathrm{Al}_{2} \mathrm{O}_{3}\right)$ and manganese oxide $(\mathrm{MnO})$ reinforcement into the $\mathrm{Y}$-TZP matrix phase at certain proportions. Phase and microstructural changes in the samples as well as their physical and mechanical properties were respectively determined by using X-ray diffraction (XRD), scanning electron microscopy (SEM) and energy dispersive X-ray (EDX) spectroscopy, Archimedes' density measurement, Vickers hardness and toughness analyses and tribology wear tests. When the results are evaluated together, it is seen that a ceramic composite sample which will be added to the content in the production of brake lining systems can be prepared from ceramic based materials and can have high mechanical property and low wear. Thus, this study clearly proposes a new different approach to current production technologies of brake pads.
\end{abstract}

*1SSorumlu yazar: Alanya Alaaddin Keykubat Üniversitesi, Rafet Kayış Mühendislik Fakültesi, Metalurji ve Malzeme Mühendisliği Bölünü, Kestel Mahallesi Konya Çimento Caddesi No:80, 07450, Alanya, Antalya, Türkiye, arife.yurdakul@alanya.edu.tr Tel:00-90-242-5106060/2534 
Keywords: Brake pad, ceramic, composite, microstructure, zirconia (Y-TZP)

\section{GíRiş}

Fren balataları, otomobillerdeki en önemli güvenlik ve performans bileşenleridir. Disk frenleri ile donanımlı bütün araçların frenleme sistemlerinin en önemli parçalarıdır. Balatalar fren diskini çift taraflı sıkıştırarak hareketin durdurulmasını sağlarlar. Fakat yüksek sürtünme değerlerine maruz kaldıkları için aşınırlar ve belirli bir süre sonunda değiştirilmeleri gerekir. Balata değişiminin ihmal edilmesi sonucu fren sisteminde arıalar meydana gelmekte ve bu arızalar kazalara yol açmaktadır [1].

Fren balatalarındaki en büyük malzeme grupları, bileşen elementlerinin kompozisyonuna bağlı olarak metalik, yarı metalik, organik ve karbon esaslı malzeme gruplarından oluşmaktadır. Genellikle çok sayıda içeriğe sahip malzeme kullanımı söz konusudur. Bu malzemeler, bağlayıcı, takviye fiber ve yapısal malzeme, dolgu malzemeleri ve sürtünme modifiye edici olarak sinıflandırılır. Ayrıca bu malzemeler, aşınma ve sürtünme performansına katkı sağlar. Asbest, fren balataları üretiminde 1989 yılına kadar yaygın bir şekilde dolgu malzemesi olarak kullanılıyordu [2]. Kanserojen yapısı nedeniyle asbest lifinin kullanımı önlenmiştir ve yeni asbestsiz sürtünme malzemesi ve fren balataları geliștirilmiștir [3]. Genellikle, endüstriyel ve tarım atıkları hammadde kaynağı olarak kullanılmıştır. $\mathrm{Bu}$ amaçla, palmiye çekirdek kabuğu kompozitinden fren balata üretimi geliştirilmiştir. Fren balataları sert ve değişken sürtünme kuvvetlerine maruz kaldığı için palmiye çekirdek kabuğu kompozitinin üretimde ana malzeme olarak kullanımının mümkün olduğu belirtilmiştir. Çalışmada başlangıç malzemesi olarak kompozit yapıda fenolik reçineler, palmiye çekirdeği kabuğu, çelik tozu, grafit ve silikon karbid kullanılmıştır [2]. Aynı şekilde, Onyeneke ve arkadaşları tarafından [4], yüksek aşınma direnci ve mukavemete sahip olan ayrıca zehirli etkisi olmayan hindistan cevizi ve salyangoz kabukları fren balata üretiminde kullanılmıştır. Bu malzemeler kolaylıkla granül haline getirilerek kompozit yapı içerisinde reçine bağlayıcı katkı malzemeleri ile birlikte kullanılmıştır [4]. Asbestsiz fren balatalarının geliştirilmesi alanında pek çok araştırma yapılmıştır. Luo ve Jang [3], aramid pulpa ile takviye edilmiş iki farklı fenolik reçineyi içeren sürtünme malzemelerinin sürtünmesini ve aşınmasını incelemişler ve iki farklı fenolik reçineyi (modifiye edilmiş novalak reçinesi) içeren otomotiv malzemelerinin sürtünme ve aşınma özelliklerini disk üzerinde sürtünme test cihazı ile gerçekleştirmişlerdir. Peter ve arkadaşları, fren uygulamaları için polimer kompozit malzemede sürtünme tabakası oluşumu üzerinde çalışmışlardır. Polimer matris kompozit sürtünme tabakasının özelliklerinin karakterizasyonu gerçekleştirilmiştir. Dagwa ve Ibhadode, hurma çekirdeği kabuğundan asbestsiz sürtünme astar malzemesi geliştirmişlerdir [3]. Mohanty and Chung tarafından, kemik külü esaslı otomotiv fren balatası geliştirilmiştir [5]. Kemik külü parçacıkları, sürtünme kompozitlerinde dolgu malzemesi olarak kullanıma imkan tanıyan bazı karakteristiklere sahiptir. Yapılan çalışmadaki kompozit bünyesinde fenolik reçine, aramid selüloz, cam fiber, potasyum titanat, grafit, alüminyum fiber ve bakır tozu gibi bileşenlerin yanısıra ağırlıkça $\% 50$ oranında kemik külü kullanılmıştır [5].

Yapılan bu çalışmalar incelendiğinde, kompozit içeriğinde kullanılan başlangıç hammaddelerin fazla bileşenden oluşması, üretim esnasında da bazı riskleri beraberinde getirecektir. İki farklı bileşende, saflığ 1 yüksek, inorganik seramik hammaddeleri ve katkı malzemesi olarak yağlayıcı ve bağlayıcıların kullanılması ile yüksek aşınma dirençli, hafif ve yüksek performanslı, içeriğe eklenecek yeni kompozit örneği gereksinimi ortaya çıkmıştır. Bu amaçla mevcut çalışmada, başlangıç hammaddeleri için seramikler arasında en çok çalışma yapılan metal oksit olan zirkonya ve alumina tercih edilmiştir.

Zirkonya kübik (C), tetragonal (T) ve monoklinik (M) formlarda bulunabilen polimorf bir yapıya sahiptir. Saf zirkonya oda 1sısında monoklinik fazdadır. Bu yap1 $1170^{\circ} \mathrm{C}$ 'a kadar stabildir. $\mathrm{Bu}$ derecenin üstüne çıkıldığında tetragonal forma, $2370^{\circ} \mathrm{C}$ 'un üzerine kadar 1sitıldığında ise kübik forma geçer. Soğuma işlemi sırasında ise $1070^{\circ} \mathrm{C}$ 'ta tetragonal monoklinik faz değişimi gerçekleşir [6]. Bu dönüşüm esnasında hacim değişikliği meydana geldiği için malzemenin parçalanmasıyla sonuçlanır. $\mathrm{Bu}$ durumu önlemek için, tetragonal fazın oda sıcaklığında kararlı hale getirilmesi gerekir. Zirkonyanın yüksek sıcaklık fazları +2 ve +3 değerlikli $\mathrm{Y}_{2} \mathrm{O}_{3}, \mathrm{CaO}, \mathrm{MgO}$ gibi oksitlerle kısmi veya tamamen kararlı hale getirilebilmektedir. Bunların arasında $\mathrm{Y}_{2} \mathrm{O}_{3}$ zirkonyayı kararlı hale getirmek için en yaygın kullanılan katkıdır. $\mathrm{Zr}^{+4}$ iyonundan daha düşük değerliğe sahip yer değiştirici katyonların ilavesi ile yükü dengelemek için kristal yapıda oksijen boşluklarına neden olmaktadır. Örneğin, $\mathrm{Zr}^{+4}$ katyonunun $\mathrm{Y}^{+3}$ ile yer değiştirmesi sonucu 1triyum, zirkonya latisine girer ve negatif net yüke yol açar. Böylece yük dengesi oksijen boşlukları ile korunur [10]. Stabilize katyonların iyonik yarıçapları ve göç eden iyon yükünün etkili olduğu Taylor ve arkadaşları tarafindan belirtilmiştir. Zirkonyaya farklı miktardaki katkıların ilavesi ile latis parametreleri, birim hücre hacmi ve mikro gerinimleri önemli ölçüde etkilemektedir [11]. $\mathrm{Zr}^{+4}$ katyonu ile $\mathrm{Y}^{+3}$ iyonik yarıçap değerleri $\left(\mathrm{Zr}^{+4}: 0,82 \AA, \mathrm{Y}^{+3}: 0,96 \AA\right)$ oldukça birbirine yakındır [12]. Polikristalin \%100 tetragonal $\mathrm{ZrO}_{2}-\mathrm{Y}_{2} \mathrm{O}_{3}$ seramikleri yüksek mukavemet ve tokluk sağlamaktadır [8]. Khamverdi ve Moshiri tarafından yapılan bir çalışmada da, 3 mol itriyum kararlaştırıcı olarak kullanıldığında çok yüksek aşınma direnci ve mekaniksel özellikler gösterdiği belirtilmiştir [9]. Malzemeye gerilim uygulandığı zaman, çatlağın ilerlemesiyle termodinamik olarak yarı kararlı olan tetragonal fazı sıcaklıktan bağımsız (athermal) olarak monoklinik yapıya dönüşebilir. $\mathrm{Bu}$ faz dönüşümü sırasında oluşan hacim değişikliği çatlağın üzerine kapanma kuvveti uyguladığında çatlağın ilerlemesini engellemektedir. Diğer bir deyişle, çatlağın ilerlemesini engelleyen tüm mekanizmaların tokluk artırıcı mekanizma olduğu bilinmektedir ve sadece zirkonya 
seramiklerine özgü bir özelliktir [7]. Dönüşüm toklaşması olarak bilinen bu durum, zirkonya esaslı seramiklerin üstün mekaniksel özelliklerini tanımlamada bir anahtar süreçtir.

Sinterlenmiş 1triyum stabilize zirkonya (Y-TZP) seramikleri yüksek kırılma tokluğu ile kesme takımları, valf klavuzları, ekstrüzyon kalıpları, aşındırıcı takımlar gibi yapısal uygulamalarda kullanım aralığına sahiptir [13]. İleri teknoloji seramik uygulamaları içerisinde yaygın kullanım alanına sahip olan $\mathrm{Al}_{2} \mathrm{O}_{3}$, son derece önemli bir malzemedir. Yüksek sertlik, kimyasal olarak tepkimeye girmeme, aşınma direnci ve ergime noktası gibi çeşitli özelliklere sahiptir. Alümina seramikleri, mukavemet değerlerini $1100^{\circ} \mathrm{C}$ 'de \%90'a kadar sürdürebilir. Refrakter malzeme grubunda, öğütücü ortamlarda, kesme takımları, yüksek sıcaklık rulmanları ve mekanik kısımların çok geniş alanlarında kullanılmaktadır [14]. Alümina katkılı zirkonya kompozit bünyesi ile zirkonya seramiklerinin sertlik artışının mümkün olduğu bilinmektedir [14-16].

$\mathrm{Bu}$ çalışma ile hali hazırda kullanılan çok bileşenli malzeme grupları yerine, çevre dostu ve az bileşenli seramik esaslı kompozit örneğinin geliştirilmesi ile bu yeni örneğin fren balata prototip bileşimlerinde kullanılabilirliği amaçlanmıştır. Üretilen kompozitin faz, mikroyapı, fiziksel, mekanik ve aşınma dayanımlarının incelenmesi gerçekleştirilmiştir. Burada, kompozit üretim yaklaşımı ile balata matris malzemesi olarak kullanılan Y-TZP ve takviye şeklinde ilave edilen $\mathrm{Al}_{2} \mathrm{O}_{3}$ veya $\mathrm{MnO}$ bileşen özelliklerinin birleşmesiyle; yüksek refrakter özellik, yüksek mekanik özellikli ve düşük aşınma gösteren yeni malzeme üretimi hedeflenmiştir.

\section{MALZEME VE YÖNTEM}

\subsection{Yığınsal Prototip Numunelerin Hazırlanması}

Bu çalışmada, zirkonya içerikli fren balatası üretimleri için yapıya eklenecek kompozitin başlangıç hammaddeleri olan zirkonya ve alümina içerikli tozlar ticari bir firmadan (Teknoceram Ltd. Şti.) temin edilmiştir. Üretim için 2 farklı toz denemelerde kullanılmıştır. Beyaz toz karışımı için öncelikle $\% 3$ mol itriya ile kararlaştırılan zirkonya (3Y-TZP) tozuna ağırlıkça \%10 alümina $\left(\mathrm{Al}_{2} \mathrm{O}_{3}\right)$ ilavesi yapılmıştır. Daha sonra kompozit bünyeye şekillendirme öncesi mukavemet artırmak amaciyla polimerik malzemeden oluşan bağlayıcı katkı malzemesi kullanılmıştır. Polimerik malzeme olan fenol formaldehid (Novalak) reçinesi bağlayıcı olarak \%1 oranında karışıma katılmıştır.

Burada iki amaç için alümina ilavesi yapılmaktadır. Birincisi elastik modülü artırmaktır. İkincisi ise tetragonal zirkonya polikristalleri (TZP) seramiklerinde kaçınılmaz olan kübik fazın tane gelişimini önleyen tane sınırı olarak görev yapmasını sağlamaktır [17]. Zirkonya-alümina kompozitlerde, malzeme içerisine alüminanın katılması malzemenin yüksek sertliğinden dolayı dönüşüm için enerji eşik seviyesini artırır. Alüminanın elastik modülü (380 GPa) zirkonyanın elastik modülünden (200 GPa) hemen hemen iki kat fazladır [17].

Siyah renkte kompozit malzeme hazırlamak için ise ağırlıça $\% 3$ mangan oksit $(\mathrm{MnO})$ takviyeli $3 \mathrm{Y}$-TZP ve bağlayıc1 polimerik malzeme içermektedir. Toz içeriğindeki mangan siyah renkte bünye oluşumunda etkilidir. Burada, prototip üretim aşamasında toz metalurjisi yönteminden yararlanılmıştır. Üretim için siyah ve beyaz olmak üzere 2 farklı tip bünyelerden numuneler hazırlanmış olup tek eksenli preste ön şekillendirme işleminden geçirilerek üretilmiştir. Üretim prosesi Şekil 1'de şematik olarak verilmiştir.

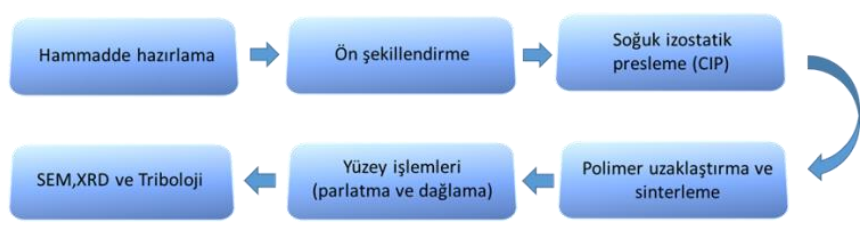

Şekil 1. Prototip üretimi için akış şeması.

Başlangıç toz kompozisyonu etanol kullanılarak hazırlanmıştır ve şekillendirme için tartım işlemi gerçekleştirilmiştir. Ardından ön şekillendirme işlemi için 40 ve $90 \mathrm{~mm}$ olmak üzere 2 farklı büyüklükte kalıp kullanılmıştır. $\mathrm{MnO}$ katkılı numunelere 4 ton, 3Y$\mathrm{TZP} / \mathrm{Al}_{2} \mathrm{O}_{3}$ katkılı numunelere 5 ton basınç uygulanmıştır. Ön şekillendirme işlemi tamamlanan numuneler, soğuk izostatik presleme (CIP) işlemi için vakumlanarak hazırlanmıştır. Vakum işlemi sonrası numuneler, CIP'te 250 $\mathrm{MPa}$ basınçta ve $1 \mathrm{dk}$ bekleme süresinde preslenmiştir. CIP ile şekillendirme sonrası numunelere ait görüntüler Şekil 2 'de verilmiştir.
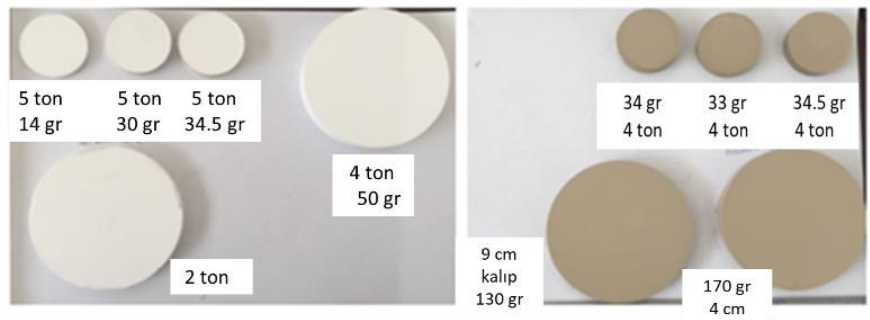

Şekil 2. Beyaz ve siyah renkli numunelerin ön şekillendirme sonras1 görüntüleri.

Polimer uzaklaştırma işlemi için, numuneler sıcaklık dakikada $0,35^{\circ} \mathrm{C}$ artacak şekilde 12 saat, sonrasında da sıcaklık dakikada $0,5^{\circ} \mathrm{C}$ artacak şekilde 10 saat firında tutulmuştur. Sıcaklığın zamana göre değişimi Şekil 3'de gösterilmektedir.

Yüksek yoğunluk değerlerine sahip yığınsal numuneler elde edebilmek için sinterleme süreci, beyaz numuneler için sicaklık dakikada $1,8^{\circ} \mathrm{C}$ artacak şekilde 15 saat, siyah numunelerde ise sicaklık dakikada $1,7^{\circ} \mathrm{C}$ artacak şekilde 14 saat fırında bekletilerek gerçekleştirilmiştir. Sicaklığın zamana göre değişimi Şekil 4 ve Şekil 5'de verilmiştir. 


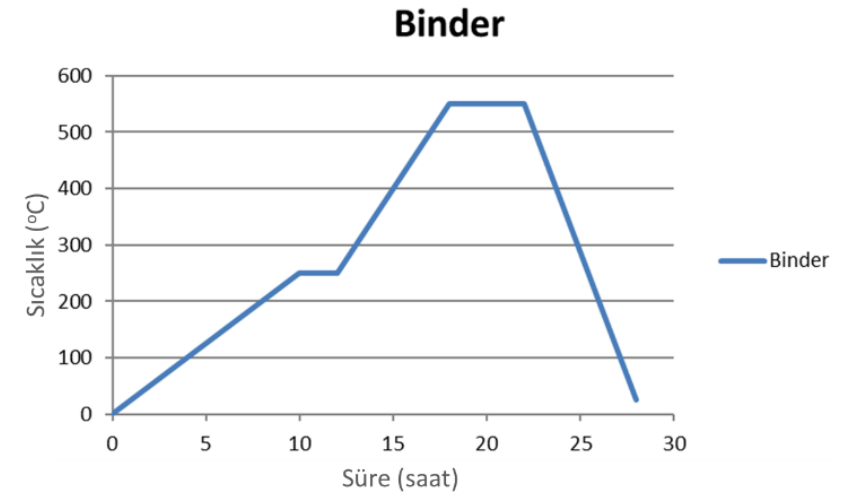

Şekil 3. Bağlayıcı uzaklaştırma işlemi için sıcaklık $\left({ }^{\circ} \mathrm{C}\right)-$ zaman (saat) grafiği.

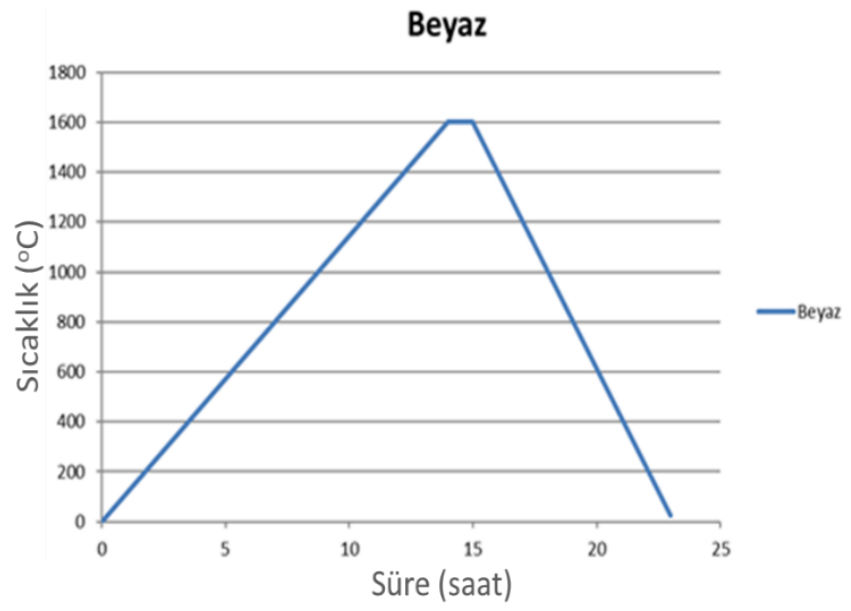

Şekil 4. Beyaz numune için sicaklık $\left({ }^{\circ} \mathrm{C}\right)$-zaman (saat) grafiği.

\section{Siyah}

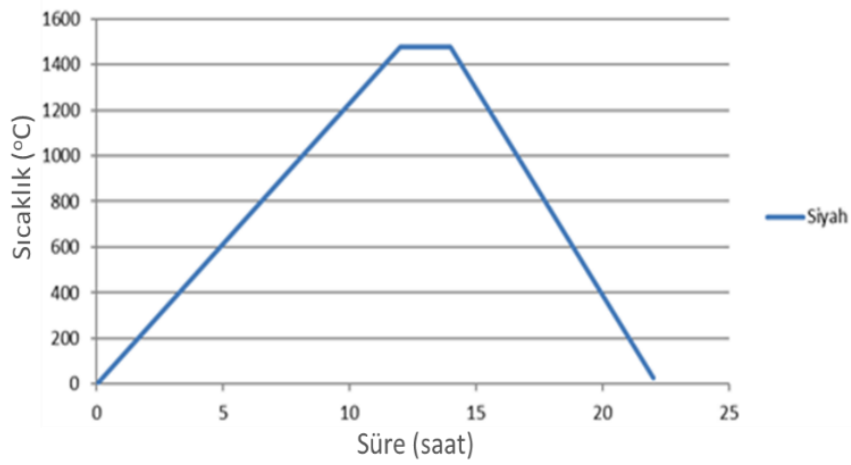

Şekil 5. Siyah numune için sicaklık $\left({ }^{\circ} \mathrm{C}\right)$-zaman (saat) grafiği.

\subsection{Uygulanan Test, Analiz ve Karakterizasyon İşlemleri}

Sinterlenen numunelerin yı̆̆ınsal yoğunlukları Arşimet prensibi ve ölçüm tekniği kullanılarak belirlenmiştir. Burada güvenilirlik açısından hem siyah hem de beyaz numuneler için 5 örneğin ortalaması alınarak yoğunluk değerleri hesaplanmıştır. Sinterleme sonrası numunelerin yüzey düzgünlüğü için geleneksel metalografi süreçlerinden yararlanılarak silisyum karbür ( $\mathrm{SiC}$ ) aşındırma kâğıtları ve elmas solüsyonlardan yararlanarak zımparalama ve parlatma işlemleri gerçekleştirilmiştir. Yeterli yüzey düzgünlüğü ve parlaklığı sağlayan numunelere oda sıcaklığında aşınma testi uygulanmıştır. Burada, aşınma testi için CSM Instrument Tribometer cihazı kullanılmıştır. İşlemde her bir numuneye $10 \mathrm{~N}$ yük altında $500 \mathrm{~m}$ mesafe ile aşınma işlemi yapılmıştır. Kullanılan uç $3 \mathrm{~mm}$ çapa sahip WC-Co bilyedir. Aşınmanın miktarı profilometre ile analiz edilmiștir. Cihaz olarak Mitutoyo SJ-400 kullanılmıştır. Numunelerin sertlik değerini belirlemek için EMCO-TEST M1C 010 cihazı kullanılarak $10 \quad \mathrm{~kg}$ yük altında Vickers indent testi yapılmıştır. Numunelerin tokluk değerleri Vickers indent izlerinden hesaplanmıştır.

Sinterlenen numunelerde XRD analizi ile faz değişimlerini belirlemek için Malvern Panalytical's Empyrean cihazı kullanılmıştır. Numune yüzeyine $\mathrm{Cu}-\mathrm{K}_{\alpha} \quad(1,5405 \AA)$ radyasyonu gönderilerek $3-80^{\circ}$ aralığındaki kırınım(lar) $1 \%$ ile toplanmıştır. Mikroyapısal incelemeler gerçekleştirmek için öncelikle numunelerin yüzeyi iletkenliği sağlamak için 15 saniye DentonVacuum Desk V Sputter cihazı kullanılarak altın (Au) ile kaplanmıştır. Sinterlenmiş numunelere ait mikroyapı görüntüleri FEI NovaNano SEM650 ve EDAX Tridient kimyasal analiz ünitesine sahip taramalı elektron mikroskobu (SEM) ve enerji saçınımlı X-1şınları (EDX) spektroskopi cihazları ile gerçekleştirilmiştir. SEM'de görüntü analizi sırasında kompozit numunelerde faz farkını ayırt edebilmek için atom numarası $(Z)$ zitlık farkına duyarlı geri yansıyan elektron görüntüleme (BSEI) detektörü ile yüksek ayırma gücü (UHR) modunda incelemeler gerçekleştirilmiştir. İncelemelerde numune yüzeyine $5,00 \mathrm{kV}$ hızlandırma voltajında elektron gönderilmiştir.

\section{BULGULAR}

Sinterlenen zirkonya essaslı kompozit numunelerin Arşimet yoğunluk analiz sonuçları değerlendirildiğinde, beyaz numunenin $\% 99,7 \pm 0,2$ ve siyah numunenin ise $\% 99,5 \pm 0,4$ yoğunluk değerlerine ulaştığı belirlenmiştir. Bu sonuç, sinterleme sürecinin başarılı bir şekilde gerçekleştirildiğini ve teorik yoğunluğa yakın yığınsal numunelerin sorunsuzca elde edildiklerini göstermektedir. Bu noktada, bu sonuca gelinceye kadar numunelerin üretim başlangıcından sinterleme sonrasına kadar, numunelerde gözlemlenen boyut ve ağırlık değişimleri Tablo 1 ve Tablo 2'de detaylı bir şekilde verilmiştir.

Burada, Tablo 1 incelendiğinde $\mathrm{Al}_{2} \mathrm{O}_{3}$ takviyeli kompozit numunelerde meydana gelen toplam küçülme miktarı ağırlıç̧a ortalama \%6 olarak belirlenmiştir. Tablo 2'deki boyutsal değişimlere ait veriler incelendiğinde, $\mathrm{MnO}$ takviyeli siyah renkli 3Y-TZP kompozitinde ise bu değerin yaklaşık ağırlıkça ortalama \%10'a çıktığı tespit edilmiştir. 
Tablo 1. Ağırlıkça \%10 $\mathrm{Al}_{2} \mathrm{O}_{3}$ takviyeli beyaz renkli 3Y-TZP kompoziti için bağlayıcı uzaklaştırma ve sinterleme sonrası boyut ve ağırlık değişimleri.

\begin{tabular}{|c|c|c|c|c|c|c|c|}
\hline & $\begin{array}{l}\text { Binder Burn- } \\
\text { Out Öncesi }\end{array}$ & $\begin{array}{l}\text { Binder Burn- } \\
\text { Out Sonrası }\end{array}$ & $\begin{array}{l}\text { \% Binder Son. } \\
\text { Küçülme\Kayıp }\end{array}$ & $\begin{array}{l}\text { Sinterleme } \\
\text { Sonrası }\end{array}$ & $\begin{array}{l}\text { \% Sinterleme Son. } \\
\text { Küçülme\Kayıp }\end{array}$ & $\begin{array}{c}\text { \% Toplam } \\
\text { Küçülme\Kayıp }\end{array}$ & \\
\hline & 14,2753 & 13,7654 & 3,571903918 & 13,3688 & 2,881136763 & 6,350129244 & $\leftarrow$ Ağırlık (gr) \\
\hline \multirow[t]{3}{*}{ Beyaz-1 } & 40,35 & 37,81 & 6,294919455 & 30,6 & 19,06902936 & 24,16356877 & $\leftarrow$ Çap $(\mathrm{mm})$ \\
\hline & 4,47 & 4,19 & 6,263982103 & 3,39 & 19,09307876 & 24,16107383 & $\leftarrow$ Boy $(\mathrm{mm})$ \\
\hline & 30,3 & 29,1358 & 3,842244224 & 28,3503 & 2,695995991 & 6,434653465 & $\leftarrow$ Ağırlık (gr) \\
\hline \multirow[t]{3}{*}{ Beyaz-2 } & 40,35 & 37,8 & 6,319702602 & 30,92 & 18,2010582 & 23,37050805 & $\leftarrow$ Cap $(\mathrm{mm})$ \\
\hline & 9,2326 & 8,6548 & 6,258258779 & 6,96 & 19,58219716 & 24,61495137 & $\leftarrow$ Boy $(\mathrm{mm})$ \\
\hline & 34,6589 & 33,4545 & 3,475009305 & 32,4942 & 2,870465857 & 6,245726206 & $\leftarrow$ Ağırlık (gr) \\
\hline \multirow[t]{3}{*}{ Beyaz-3 } & 40,35 & 37,81 & 6,294919455 & 30,92 & 18,22269241 & 23,37050805 & $\leftarrow$ Cap $(\mathrm{mm})$ \\
\hline & 13,22 & 12,4 & 6,202723147 & 9,98 & 19,51612903 & 24,50832073 & $\leftarrow$ Boy $(\mathrm{mm})$ \\
\hline & 128,8003 & 124,0236 & 3,708609374 & 120,5064 & 2,835911875 & 6,439348356 & $\leftarrow$ Ağırlık (gr) \\
\hline \multirow[t]{3}{*}{ Beyaz-4 } & 83,42 & 77,97 & 6,533205466 & 63,35 & 18,75080159 & 24,05897866 & $\leftarrow$ Cap $(\mathrm{mm})$ \\
\hline & 9,39 & 8,79 & 6,389776358 & 7.13 & 18,8850967 & 24,06815761 & $\leftarrow$ Boy $(\mathrm{mm})$ \\
\hline & 187,4563 & 180,6189 & 3,647463435 & 175,4555 & 2,858726302 & 6,401918741 & $\leftarrow$ A ğırlık (gr) \\
\hline \multirow[t]{2}{*}{ Beyaz-5 } & 83,47 & 77.72 & 6,888702528 & 64,27 & 17,30571282 & 23,00227627 & $\leftarrow$ Cap $(\mathrm{mm})$ \\
\hline & 12,52 & 11,7 & 6,549520767 & 9,49 & 18,88888889 & 24,20127796 & $\leftarrow$ Boy $(\mathrm{mm})$ \\
\hline
\end{tabular}

Tablo 2. Ağırlıkça \%3 MnO takviyeli beyaz renkli 3Y-TZP kompoziti için bağlayıcı uzaklaştırma ve sinterleme sonrası boyut ve ağırlık değişimleri.

\begin{tabular}{|c|c|c|c|c|c|c|c|}
\hline & $\begin{array}{l}\text { Binder Burn- } \\
\text { Out Öncesi }\end{array}$ & $\begin{array}{l}\text { Binder Burn- } \\
\text { Out Sonrası }\end{array}$ & $\begin{array}{l}\text { \% Binder Son. } \\
\text { Küçülme\Кауıр }\end{array}$ & $\begin{array}{l}\text { Sinterleme } \\
\text { Sonrası }\end{array}$ & $\begin{array}{l}\text { \% Sinterleme Son. } \\
\text { Küçülme\Kayıp }\end{array}$ & $\begin{array}{c}\text { \% Toplam } \\
\text { Küçülme\Кayıp }\end{array}$ & \\
\hline & 33,2324 & 30,5389 & 8,105042067 & 29,7238 & 2,669054878 & 10,55776892 & $\leftarrow$ Ağırlık (gr) \\
\hline \multirow[t]{3}{*}{ Siyah-1 } & 40,35 & 37,81 & 6,294919455 & 29,9 & 20,92039143 & 25,8983891 & $\leftarrow$ Çap $(\mathrm{mm})$ \\
\hline & 9,64 & 8,85 & 8,195020747 & 7,22 & 18,4180791 & 25,10373444 & $\leftarrow$ Boy $(\mathrm{mm})$ \\
\hline & 36,2722 & 33,3101 & 8,166309184 & 32,3741 & 2,809958541 & 10,74679782 & $\leftarrow$ Ağırlık (gr) \\
\hline \multirow[t]{4}{*}{ Siyah-2 } & 40,38 & 38,73 & 4,086181278 & 30,28 & 21,81771237 & 25,01238237 & $\leftarrow$ Çap $(\mathrm{mm})$ \\
\hline & 10,15 & 9,28 & 8,571428571 & 7,6 & 18,10344828 & 25,12315271 & $\leftarrow$ Boy $(\mathrm{mm})$ \\
\hline & & & & & & & \\
\hline & 35,5541 & 32,6538 & 8,157427695 & 31,7183 & 2,864903932 & 10,78862916 & $\leftarrow$ Ağırlık (gr) \\
\hline \multirow[t]{3}{*}{ Siyah-3 } & 40,35 & 37,81 & 6,294919455 & 29,94 & 20,81459931 & 25,79925651 & $\leftarrow$ Çap $(\mathrm{mm})$ \\
\hline & 10,16 & 9,31 & 8,366141732 & 7,62 & 18,15252417 & 25 & $\leftarrow$ Boy $(\mathrm{mm})$ \\
\hline & 141,5004 & 130,0221 & 8,11184986 & 126,2378 & 2,910505214 & 10,78625926 & $\leftarrow$ Ağırlık (gr) \\
\hline \multirow[t]{3}{*}{ Siyah-4 } & 83,42 & 77,97 & 6,533205466 & 63,16 & 18,99448506 & 24,28674179 & $\leftarrow$ Çap $(\mathrm{mm})$ \\
\hline & 9,13 & 8,34 & 8,65279299 & 6,8 & 18,46522782 & 25,52026287 & $\leftarrow$ Boy $(\mathrm{mm})$ \\
\hline & 151 & 138,6531 & 8,176754967 & 134,5775 & 2,939422198 & 10,87582781 & $\leftarrow$ Ağırlık (gr) \\
\hline \multirow[t]{2}{*}{ Siyah-5 } & 83,47 & 77,72 & 6,888702528 & 63,14 & 18,75965003 & 24,35605607 & $\leftarrow$ Çap $(\mathrm{mm})$ \\
\hline & 9,62 & 8,82 & 8,316008316 & 7,21 & 18,25396825 & 25,05197505 & $\leftarrow$ Boy $(\mathrm{mm})$ \\
\hline
\end{tabular}


Sinterleme sonrasında yığınsal olarak yüksek yoğunlukta elde edilen beyaz (B) ve siyah (S) olarak kodlanmış sırasıyla $\mathrm{Al}_{2} \mathrm{O}_{3}$ ve $\mathrm{MnO}$ takviyeli kompozit numunelere uygulanan triboloji aşınma test sonuçları Şekil 6, Şekil 7 ve Şekil 8'de gösterilmiştir.

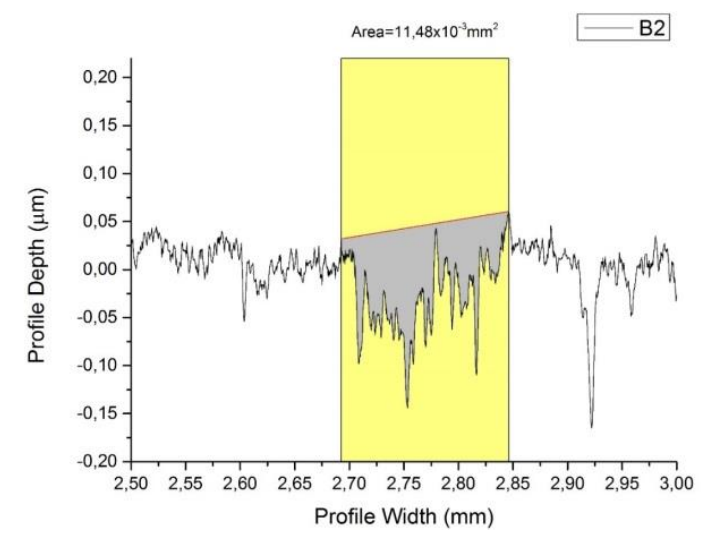

Şekil 6. Beyaz numunenin ( $\left.3 \mathrm{Y}-\mathrm{TZP} / \mathrm{Al}_{2} \mathrm{O}_{3}\right)$ aşınma oranı.

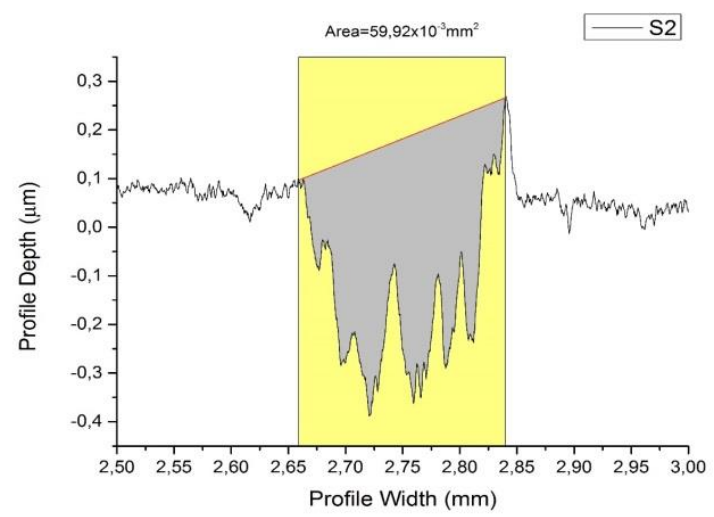

Şekil 7. Siyah numunenin (3Y-TZP/MnO) aşınma oranı.

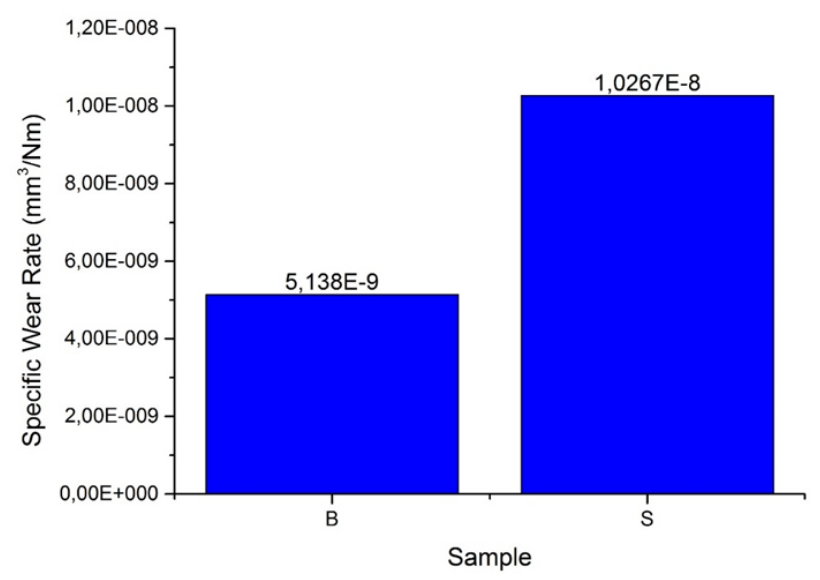

Şekil 8. Numunelere ait özgül aşınma oranı.

Şekil 6-8'deki triboloji aşınma sonuçları birlikte değerlendirildiğinde, $3 \mathrm{Y}-\mathrm{TZP} / \mathrm{MnO}$ yani siyah (S) renkteki kompozit numunelerinin özgül aşınma oranının, beyaz renkli
(B) $3 \mathrm{Y}-\mathrm{TZP} / \mathrm{Al}_{2} \mathrm{O}_{3}$ numunelerine göre 2 kat daha fazla olduğu görülebilmektedir. Burada, $\mathrm{MnO}$ kıyasla aşınma direnci ve sertlik değeri yüksek olan $\mathrm{Al}_{2} \mathrm{O}_{3}$ 'nın sisteme ilave edilmesiyle birlikte aşınma direncinin artışı yönünde önemli ve olumlu bir katk1 yaptığı söylenebilmektedir.

Oda sıcaklığında gerçekleştirilen aşınma deneyi sonucunda, sürtünme katsayısı değerleri beyaz renkli (B) $3 \mathrm{Y}-\mathrm{TZP} / \mathrm{Al}_{2} \mathrm{O}_{3}$ numunesi için 0,34825 iken $3 \mathrm{Y}-\mathrm{TZP} / \mathrm{MnO}$ bileşimine sahip siyah (S) renkteki kompozit numuneleri için bu değer 0,28794 olarak belirlenmiştir.

Elde edilen bu sonucu sağlamlaştırmak adına beyaz ve siyah numuneye Vickers sertlik analizi uygulanmış ve indent izlerinden numunelere ait tokluk değerleri de hesaplanmıştır. Şekil 9'da bu mekanik analizleri temsilen siyah numuneden elde edilen Vickers indent izi gösterilmiştir.

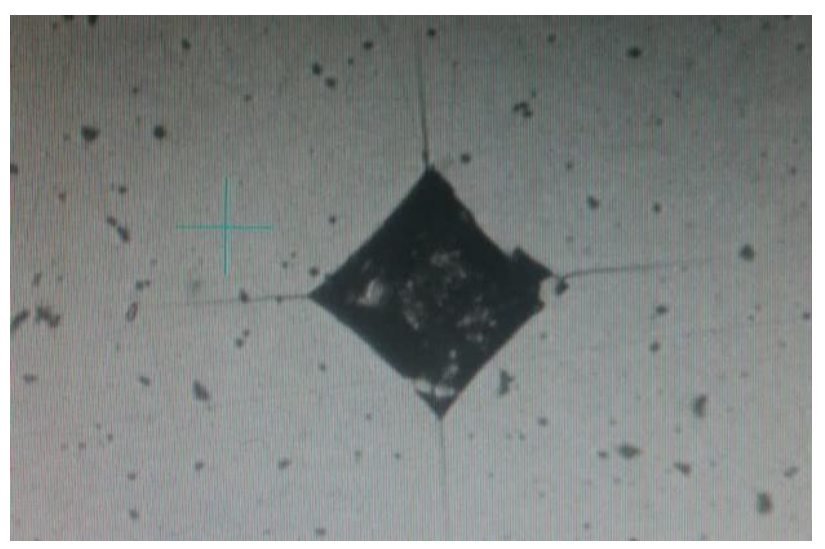

Şekil 9. Siyah renkli zirkonya (3Y-TZP/MnO) numunesine ait Vickers indent görüntüsü.

Sertlik ve kırılma tokluğu değerleri için beyaz ve siyah numunelere 3 farklı noktadan ölçüm yapılmış ve ortalama değerler alınarak hesaplamalar gerçekleştirilmiştir. $1600^{\circ} \mathrm{C}$ 'de sinterlenen beyaz renkli $3 \mathrm{Y}-\mathrm{TZP} / \mathrm{Al}_{2} \mathrm{O}_{3}$ kompozitlerine uygulanan Vickers testi sonucunda $10 \mathrm{~kg}$ 'l1k yük altında ortalama sertlik değerlerinin $14,52 \pm 0,5 \mathrm{GPa}$, kırılma tokluğu değerinin ise ortalama $5.81 \pm 0,4 \mathrm{MPa}^{1 / 2}$ olduğu belirlenmiştir. $1550^{\circ} \mathrm{C}$ 'de sinterlenen siyah renkteki $3 \mathrm{Y}-\mathrm{TZP} / \mathrm{MnO}$ numuneleri için ise sertlik değeri $12,13 \pm 0,7$ $\mathrm{GPa}$, kırılma tokluğu değeri $5,12 \pm 0,3 \mathrm{MPa}^{1 / 2}$ tespit edilmiştir. $\mathrm{Bu}$ değerler incelendiğinde, beyaz numunenin mekanik özelliklerinin siyah numuneye göre daha iyi olduğu söylenebilir. Dönüşüm toklaştırma mekanizması, itriyum ile stabilize olan zirkonya seramiklerinin tokluk değerini artırmakta etkisi büyüktür. Burada, basınç uygulanan noktaların çevresinde kılcal çatlakların oluştuğu saptanmıştır. Kuo ve arkadaşları [18], \%3-5 mol $\mathrm{Y}_{2} \mathrm{O}_{3}$ içeriğine sahip zirkonya seramiklerinin tetragonal fazdan monoklinik faza dönüşümünün yüksek mukavemet ve kırılma tokluğu ile sonuçlandığını açıkça belirtilmiştir. Dolayısıyla buradan, bu çalışmada belirlen tokluk-sertlik değerlerinin, Şekil 6-8'deki aşınma testi sonuçları ile oldukça uyumlu olduğu söylenebilmektedir. 
Beyaz ve siyah renkli kompozit numuneler içerisinde sinterleme sonrasında meydana gelen faz değişimlerini tespit etmek için gerçekleştirilen XRD analiz sonuçları sırasıyla Şekil 10 ve Şekil 11'de verilmiştir.

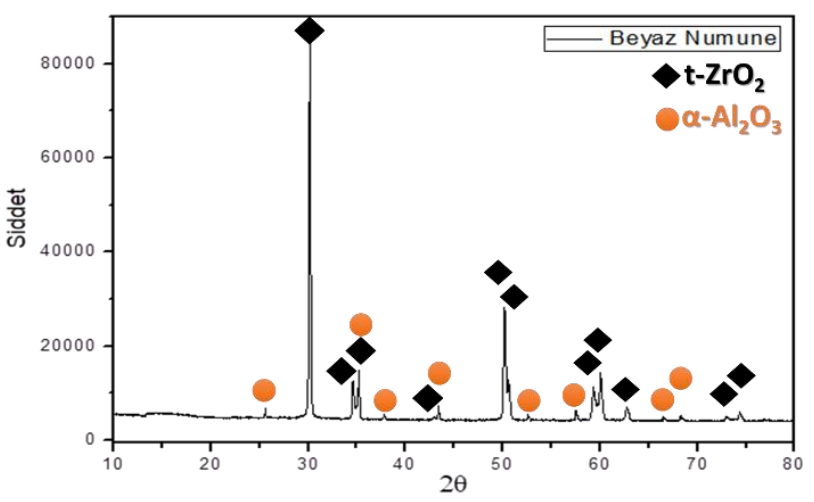

Şekil 10. Beyaz numunenin $\left(3 \mathrm{Y}-\mathrm{TZP} / \mathrm{Al}_{2} \mathrm{O}_{3}\right) \mathrm{XRD}$ paterni.

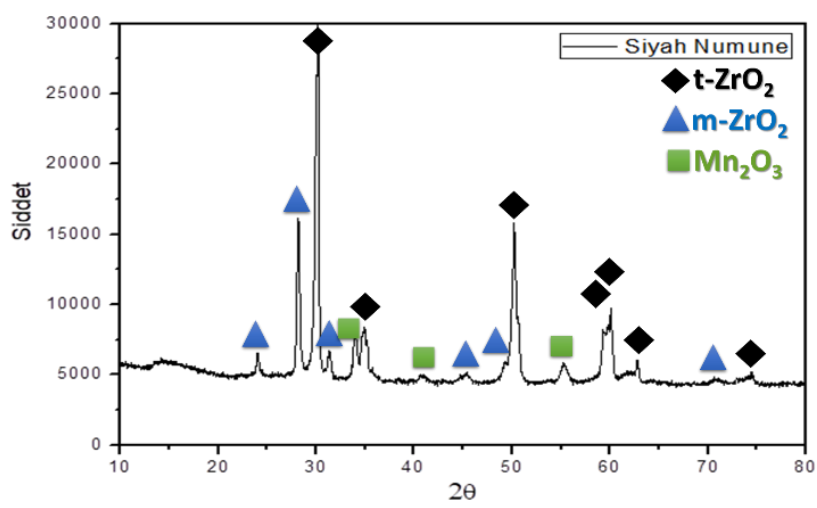

Şekil 11. Siyah numunenin (3Y-TZP/MnO) XRD paterni.

Şekil 10 ve Şekil 11'de sunulan XRD grafikleri incelendiğinde, beyaz renkli $3 \mathrm{Y}-\mathrm{TZP} / \mathrm{Al}_{2} \mathrm{O}_{3}$ kompozit numunesinin tetragonal zirkonya $\left(\mathrm{t}-\mathrm{ZrO}_{2}\right)$ ve korundum $\left(\mathrm{Al}_{2} \mathrm{O}_{3}\right)$ piklerinden, siyah renkli 3Y-TZP/MnO kompozit numunesinin ise tetragonal zirkonya $\left(\mathrm{t}-\mathrm{ZrO}_{2}\right)$, badeleyitmonoklinik zirkonya $\left(\mathrm{m}-\mathrm{ZrO}_{2}\right)$ ve mangan (III) oksit $\left(\mathrm{Mn}_{2} \mathrm{O}_{3}\right)$ fazlarından oluştuğu görülmektedir. $\mathrm{Bu}$ sonuçlar doğrultusunda, sinterleme sonrasında kompozit numune bileşenlerinden farklı bir pike rastlanılmamış olması, kompozit üretim yaklaşımının sinterleme sürecinde başarıyla uygulandığını göstermektedir. Bununla birlikte, siyah numunede belirlenen badeleyit ve $\mathrm{Mn}_{2} \mathrm{O}_{3}$ fazlarının, sinterleme sürecinin 1sitma ve/veya soğtuma kademesinde t$\mathrm{ZrO}_{2} \rightarrow \mathrm{m}-\mathrm{ZrO}_{2}$ faz dönüşümleri ile birlikte $2 \mathrm{MnO}_{(\mathrm{k})}+1 / 2 \mathrm{O}_{2(\mathrm{~g})} \rightarrow \mathrm{Mn}_{2} \mathrm{O}_{3(\mathrm{k})}$ yükseltgenme reaksiyonuyla geliştiği düşünülmektedir. Dolayısıyla, sinterleme sürecinde gelişen bu fazlar, 3Y-TZP/MnO kompozit numunesinde neden daha düşük bir tokluk değerine $\left(5,12 \pm 0,3 \mathrm{MPa} \cdot \mathrm{m}^{1 / 22}\right)$ ulaşıldığını açıklamaktadır. Çünkü, sinterlenmiş 3Y-TZP bünye içerisindeki $\mathrm{m}-\mathrm{ZrO}_{2}$ faz içeriğinin artması ve mangan oksitin bulunması, tokluk değerinin azalmasına neden olduğu bildirilmiştir [19-20].

Şekil 12 (a-d)'de beyaz renkli $3 \mathrm{Y}-\mathrm{TZP} / \mathrm{Al}_{2} \mathrm{O}_{3}$ kompozit numunesine ait SEM ve EDX analizleri ile kaydedilen mikroyapısal görüntüleme ve kimyasal analiz sonuçları sunulmuştur. Burada, öncelikle SEM görüntüleri incelendiğinde, takviye malzemesi olarak kullanılan $\mathrm{Al}_{2} \mathrm{O}_{3}$ tanelerinin $\mathrm{t}-\mathrm{ZrO}_{2}$ matris fazı içerisindeki dağılımının homojen olduğu görülmüş ve numune hazırlama hatalarından dolayı numune yüzeyinde herhangi bir tane kopması veya bu nedenle gelişen çatlaklara rastlanılmamıştır. Bununla birlikte, SEM-BSE görüntülerindeki (Şekil $12(\mathrm{a}-\mathrm{c})$ ), siyah renkli taneler daha düşük atom numaralı $\mathrm{Al}_{2} \mathrm{O}_{3}$ fazını, gri renkli taneler ise yüksek atom numarasından dolayı $\mathrm{t}-\mathrm{ZrO}_{2}$ fazını temsil etmektedir. Ayrica, hem $\mathrm{Al}_{2} \mathrm{O}_{3}$ hem de $\mathrm{t}-\mathrm{ZrO}_{2}$ tanelerinin mikroyapı genelinde çoğunlukla mikron altı seviyesinde tane boyutuna sahip bir şekilde dağıldıkları gözlemlenebilmektedir Daha ötesinde, tane yüzeylerinde zirkonyanın $\mathrm{t}-\mathrm{ZrO}_{2} \rightarrow \mathrm{m}-\mathrm{ZrO}_{2}$ faz dönüşümleri sebebi ile mikro çatlakların oluştuğu fark edilebilmektedir. $\mathrm{Bu}$ sonuçlar, $3 \mathrm{Y}-\mathrm{TZP} / \mathrm{Al}_{2} \mathrm{O}_{3}$ kompozit numunesinde neden daha yüksek bir tokluk değerinin $\left(5.81 \pm 0,4 \quad \mathrm{MPa}^{1 / 2}\right)$ elde edildiğini doğrular niteliktedir. Şekil 12 (d)'de sunulan SEM-EDX analizi sonucuna bakıldığında, $3 \mathrm{Y}-\mathrm{TZP} / \mathrm{Al}_{2} \mathrm{O}_{3}$ kompozit numunesinin $\mathrm{Zr}, \mathrm{Al}, \mathrm{O}$ ve $\mathrm{Y}$ elementlerinden oluştuğu doğrulanmıştır. $\mathrm{Bu}$ sonuç, XRD analizinde gözlemlendiği gibi (Şekil 10), buradaki SEM-EDX analizi ile de; sinterleme sürecinde atmosferden kaynaklı herhangi bir kirliliğin veya ikinci bir yabancı fazın sistemde bulunmadığını doğrulamaktadır.

Şekil 13'de beyaz renkli $3 \mathrm{Y}-\mathrm{TZP} / \mathrm{Al}_{2} \mathrm{O}_{3}$ kompozit numunesinden kaydedilen nicel SEM-EDX elementel haritalama sonuçları verilmiştir. Burada, görüntünün her bir pikseli üzerindeki yeşil noktalar oksijen (O), kırmızı noktalar alüminyum (Al), gri noktalar itriyum $(\mathrm{Y})$ ve pembe noktalar ise zirkonyumun $(\mathrm{Zr})$ nicel olarak bulunduğu bölgeleri temsil etmektedir. Her ne kadar EDX analizinin ayırma gücünden dolayı sonuçları tam bir nicel analiz olarak değerlendiremesek te, en azından genel mikroyapı içerisinde elementlerin hangi miktarlarda nerelerde nicel olarak yoğunlaştığı hakkında ön bilgi almak açısından kaydedilen sonuçların değerli olduğu düşünülmektedir. Nitekim, sisteme ağırlıkça \%10 olarak katıldığı bilinen Al'un, burada (Şekil 13) elde edilen sonuçlara göre, \%8 oranında sistemde bulunduğu tespit edilmiştir.

Şekil 14 (a-d)'de ise siyah renkli 3Y-TZP/MnO kompozit numunesine ait SEM ve EDX analizleri verilmiştir. Buna göre, numunede yer yer tane kopmalarının ve tane büyümesinin meydana geldiği görülmektedir. Ayrıca, tane yüzeyinde bölgesel katmanlar şeklinde mikro çatlakların oluştuğu görülmüştür (Şekil 14 (a-c)).

Siyah renkli 3Y-TZP/MnO kompozitinde tek bir tane yüzeyinden yapılan EDX analiz sonuçlarına göre, Mn elementinin \% miktarı kompozisyon içerisinde düşük 
olduğundan saptanamamıştır (Şekil 14(d)). Ancak, Şekil 15 'de verilen nicel SEM-EDX elementel haritalamasinda, sistemde ağırlıkça \%3 miktarında olduğu bilinen Mn, \%2 olarak tespit edilmiştir.
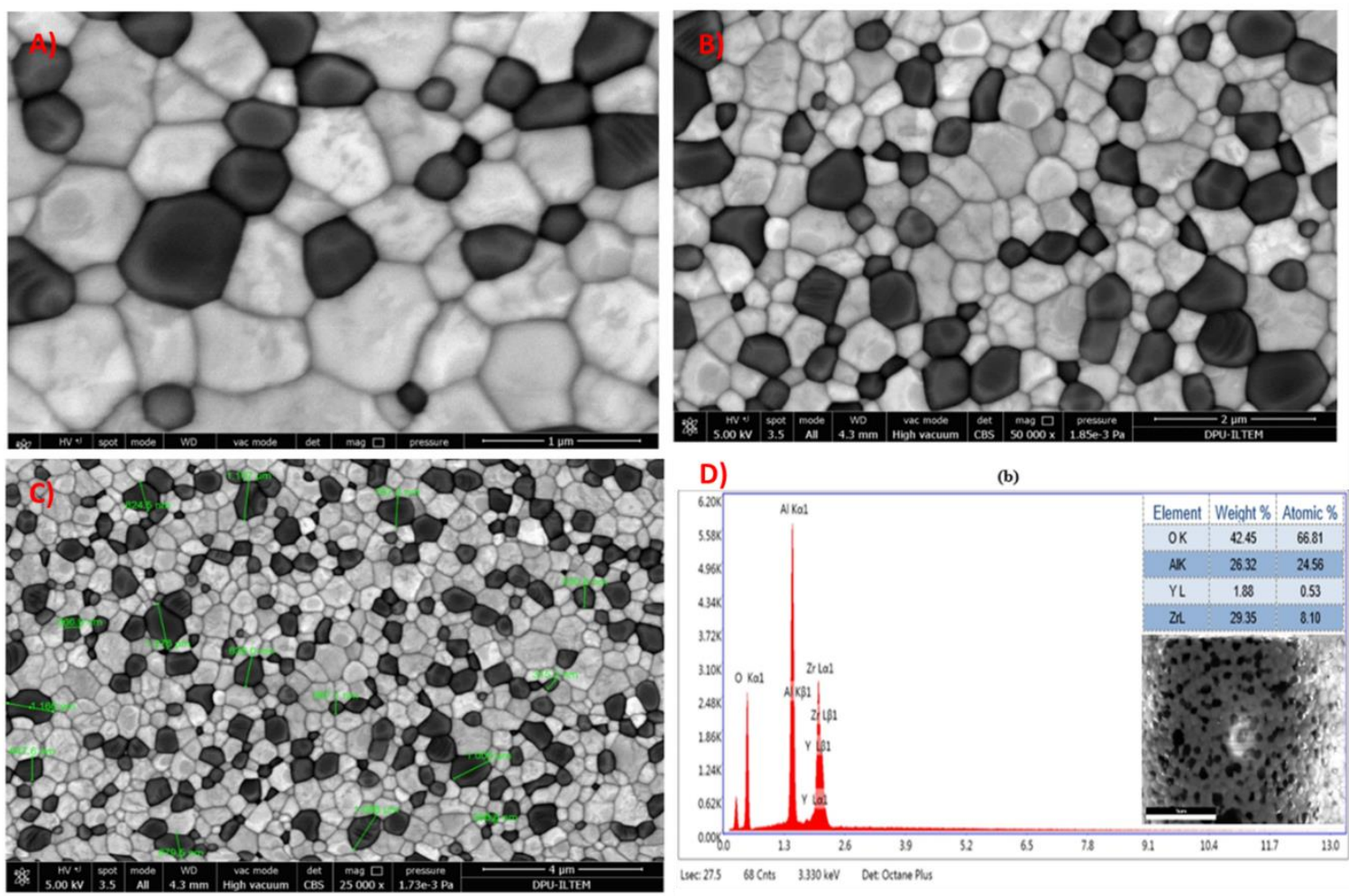

Şekil 12. Beyaz numunenin (3Y-TZP/Al $\mathrm{O}_{3}$ ) a) 100000X, b) 50000X, c) 25000X büyütme değerlerindeki SEM-BSE görüntüleri ve d) EDX analizi sonuçları.
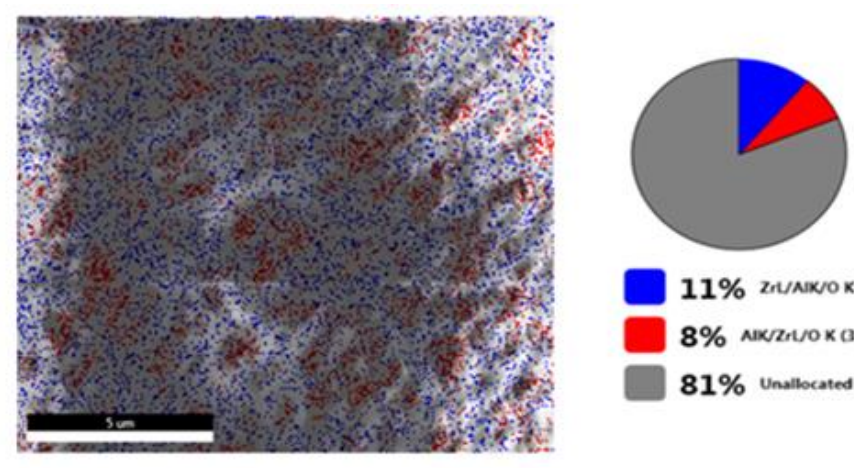

11\% ZTUNANO K (5624 Pixels)

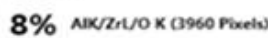

$\mathbf{8 1 \%}$ Unallocated (41616 Pixels

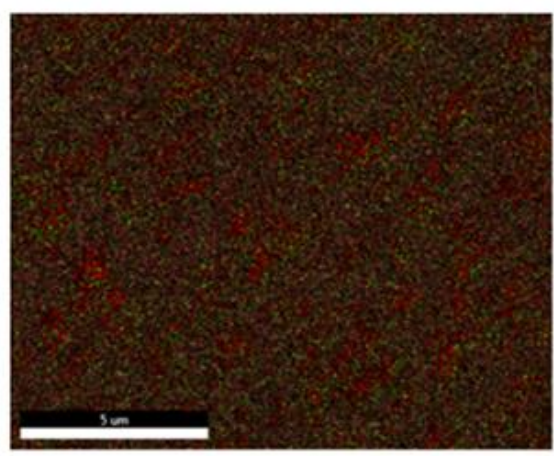

$15 \%$ O K

$28 \%$ AIK

$\mathbf{9 \%} \mathbf{Y} \mathbf{L}$

$48 \% \mathrm{ZrL}$

Şekil 13. Beyaz numunenin $\left(3 \mathrm{Y}-\mathrm{TZP} / \mathrm{Al}_{2} \mathrm{O}_{3}\right)$ nicel SEM-EDX elemental haritalama sonuçlar1. 

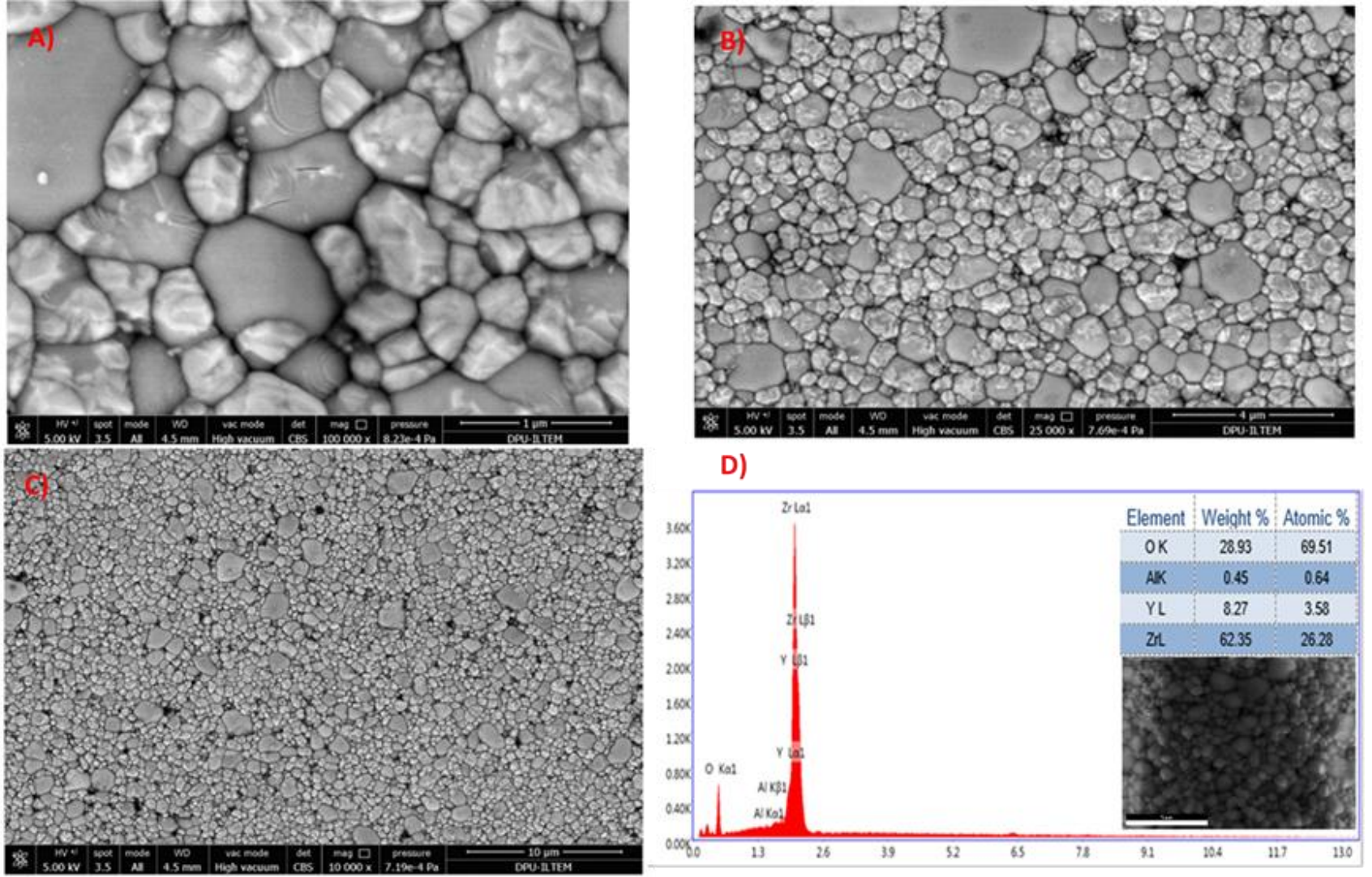

Şekil 14. Siyah numunenin (3Y-TZP/MnO) a) 100000X, b) 25000X, c) 10000X büyütme değerlerindeki SEM-BSE görüntüleri ve d) EDX analizi sonuçları.
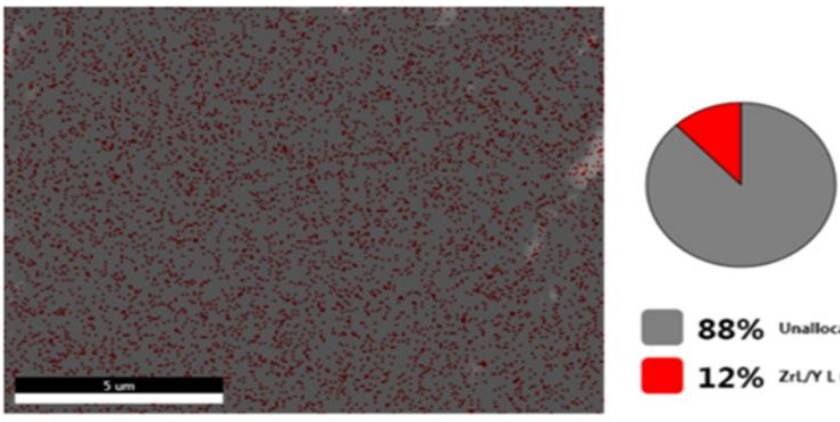

88\% Unallocated (45036 Pixels)

12\% zrivL (6164 Pixels)

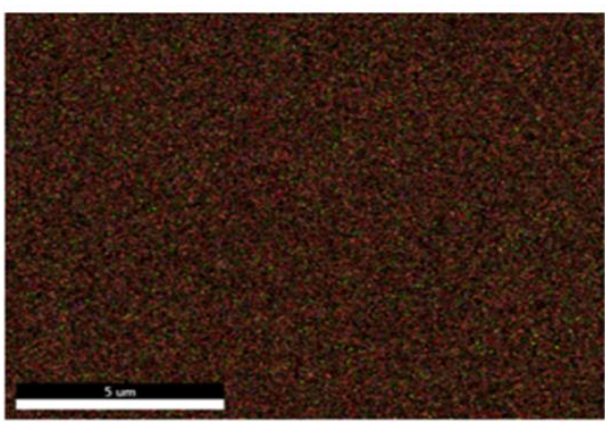

$9 \%$ ○ K

3\% AIK

$13 \% \quad \mathrm{~V}$

$73 \% \mathrm{ZrL}$

2\% MnK

Şekil 15. Siyah numunenin (3Y-TZP/MnO) nicel SEM-EDX elemental haritalama sonuçları. 


\section{DEĞERLENDIRME ve SONUÇ}

Kompozit malzeme üretim yaklaşımı ile 3Y-TZP matris fazı içerisine aynı üretim sürecinde farklı takviye malzemeleri $\left(\mathrm{Al}_{2} \mathrm{O}_{3}\right.$ ve $\left.\mathrm{MnO}\right)$ katılarak üretilmiş numunelerden, 3Y$\mathrm{TZP} / \mathrm{Al}_{2} \mathrm{O}_{3}$ kompoziti şeklinde üretilen prototipin aşınma ve mekanik test sonuçlarının, 3Y-TZP/MnO numunesine göre daha iyi olduğu söylenebilir. Burada, her iki numunenin kompozisyonları incelendiğinde, malzeme içeriğindeki $\mathrm{Al}_{2} \mathrm{O}_{3}$ miktarının aşınma direncinin ve mekanik özelliklerin iyileşmesinde etken rol oynadığı görülebilmektedir. Çünkü MnO'e göre $\mathrm{Al}_{2} \mathrm{O}_{3}$ 'nın daha yüksek sertlik ve elastiklik modülüne sahip olması [17], nihai kompozitlerin son özelliklerinin (sertlik, tokluk ve aşınma oranı) gelişimi üzerinde olumlu yönde bir etki sergilemiștir. Bununla birlikte, XRD ve SEM analizleri ile kaydedilen faz ve mikroyapısal değişimler beraber değerlendirildiğinde, t$\mathrm{ZrO}_{2}$ ve korundum fazlarının homojen bir şekilde mikron altı seviye bir tane boyut dağılımı ile gelişmiş olması, 3Y$\mathrm{TZP} / \mathrm{Al}_{2} \mathrm{O}_{3}$ kompozitinin neden yüksek sertlik, tokluk ve aşınma direnci gösterdiğini açıklar niteliktedir. Ancak, 3Y$\mathrm{TZP} / \mathrm{MnO}$ numunesinde ise sinterlenme sürecine bağl olarak gelişen $\mathrm{m}-\mathrm{ZrO}_{2}$ ve mangan (III) oksit gibi zirkonyanın mekanik özelliklerini olumsuz yönde etkileyen [19-22] yeni fazların geliştirdiği homojen olmayan ve tane büyümesi ile sonuçlanmış bir içyapı mevcuttur. Bu durum kompozitteki daha düşük mekanik özellikler ve daha yüksek aşınma miktarlarını açıklamaktadır. Deneysel sonuçlar tekrar değerlendirildiğinde, her ne kadar 3Y-TZP/MnO numunesinin fren balatasında kullanılabilecek bir kompozit örneği olarak değerlendirilme potansiyeli olsa da, kullanıma yönelik olarak $3 \mathrm{Y}-\mathrm{TZP} / \mathrm{Al}_{2} \mathrm{O}_{3}$ bileşimi ile üretilen kompozit prototipinin balatada kullanımının daha uygun olacağ düşünülmüştür.

$\mathrm{Bu}$ çalışmada, fren balatalarının içeriğine eklenecek bir kompozit örneği olarak kullanılmak üzere toz metalürjisi üretim yöntemi ile $3 \mathrm{Y}-\mathrm{TZP} / \mathrm{Al}_{2} \mathrm{O}_{3}$ ve $3 \mathrm{Y}-\mathrm{TZP} / \mathrm{MnO}$ bileşimlerinde hazırlanan tozların sinterlenmesi sonrasında yüksek kırılma tokluğu, sertlik ve aşınma direnci değerlerine sahip yığınsal ürünler elde edilmiştir. Burada, çok bileşenli metal ve polimerik malzemelerden fren balatası üretimi yerine, tamamen seramik esaslı en fazla iki bileşene sahip balatalar için yeni bileşim çalışmaları gerçekleştirilmiştir. Genel olarak, seramik içerikli fren balataları diğer malzeme grupları ile karşılaştırıldığında; daha hafif, aynı zamanda sessiz çalışma imkânı ve daha yüksek aşınma direnci ile

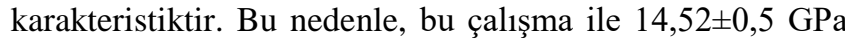

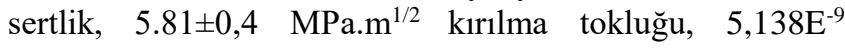
$\mathrm{mm}^{2} / \mathrm{Nm}$ özgül aşınma oranı ve $\approx 0,35$ sürtünme katsayısı değerlerinde fren balataları için yeni bir bileşen elde edilmiştir. Üretilmiş olan beyaz renkli $3 \mathrm{Y}-\mathrm{TZP} / \mathrm{Al}_{2} \mathrm{O}_{3}$ kompozitinin, sanayide seri üretime ve gelecekte araçlarda kullanıma uygun olabileceği düşünülmektedir. Böylece, Ülkemiz Otomotiv Sanayisine önemli bir katkı sağlanacağ beklenmektedir. Bununla birlikte, bu çalışma kapsamında elde edilen aşınma-sürtünme sonuçları yüksek sıcaklıklarda da tekrarlanması kaydıyla, geliştirilen bu yeni bileşiminin yüksek sıcaklık performans aşınma-sürtünme özellikleri yeni bir çalışma olarak gerçekleştirebilir.

\section{TEȘEKKÜR}

Bu çalışma, "Tübitak 2209B-Sanayi Odaklı Lisans Bitirme Tezi Destekleme Programı" kapsamında desteklenmiştir. Prototip zirkonya kompozitlerinin üretimi için sağladığı kolaylık ve firsattan dolayı Teknoceram Ltd. Şti. Müdürü Doç. Dr. Hilmi YURDAKUL'a teşekkür ederiz.

\section{KAYNAKÇA}

[1] R. Ertan, and N. Yavuz, "Balata malzemelerinde kullanılan yapısalların balatanın tribolojik ve fiziksel özelliklerine etkisi", Uludağ University Journal of The Faculty of Engineering, Say1 1, Nisan 2010.

[2] Z. U. Elakhame, O. A. Alhassan and A. E. Samuel, "Development and production of brake pads from palm kernel shell composite", International Journal of Scientific \& Engineering Research, vol 5, no 10, pp. 735-744, October 2014.

[3] Y. Aku Shakerau, S. G. Amaren and S. Yawas Danjuma, "Evaluation of the wear and thermal properties of asbestos free brack pad using periwinkles shell particles", Usak University Journal of Material Sciences, Sayı 1, 2013.

[4] F. N. Onyeneke, J. U. Anaele and C. C. Ugwuegbu, "Production of motor vehicle brake pad using local materials (perriwinkle and coconut shell)", The International Journal Of Engineering And Science (IJES), vol. 3, no 9, pp. 17-24, September 2014.

[5] S. Mohanty and Y. P. Chugh, "Development of fly ashbased automotive brake lining", Tribology International, vol. 40, no 7, pp. 1217-1224, February 2007.

[6] Ö. Bultan, D. Öngül, and P. Türkoğlu, "Zirkonyanın mikroyapılarına ve üretim şekillerine göre sınıflandırılması”, İstanbul Üniversitesi Diş hekimliği Fakültesi Dergisi, Sayı 2, 2010 .

[7] C. K. Muoto, E. H. Jordan, M. Gell and M. Aindow, "Phase homogeneity in $\mathrm{MgO}-\mathrm{ZrO} 2$ nanocomposites synthesized by a combined sol-gel/thermal decomposition route" Journal of the American Ceramic Society, vol. 93, no 10, pp. 3102-3109, May 2010.

[8] H. A. Abbas, F. F. Hamad, A. K. Mohamad, Z.M. Hanafi, and M. Kilo, "Structural properties of zirconia doped with some oxides", Diffusion Fundamentals, Sayı 8, 2008.

[9] A. K. Bandyopadhyay, Nano Materials, New Age International Publisher, New Delhi, 2010.

[10] G. S. A. M. Theunissen, A. J. A. Winnubst, A. J. Burggraaf, "Effect of dopants on the sintering behaviour and stability of tetragonal zirconia ceramics", Journal of the European Ceramic Society, vol. 9, no 4, pp. 251-263, 1992. [11] Z. Khamverdi and Z. Moshiri, "An up-to date Literature Review”, Avicenna J. Dent. Res., vol. 4, no 1, pp. 1-15, 2012. [12] R. Marin, G. Sponchia, E. Zucchetta, P. Riello, F. Enrichi, G. D. Portu and A. Benedetti, "Monitoring the $\mathrm{t} / \mathrm{m}$ martensitic phase transformation by photoluminescence emission in $\mathrm{Eu}^{+3}$ - doped zirconia powders", J. Am. Ceram. Soc, vol. 96, no 8, pp. 2628-2635, April 2013. 
[13] M. Mazaheri, A. Simchi, F. Golestani-Fard, "Densification and grain growth of nanocrystalline 3Y-TZP during two-step sintering", Journal of the European Ceramic Society, vol. 28, no 15, pp. 2933-2939, November 2008.

[14] A. Senthil Kumar, A. Raja Durai, T. Sornakumar, "Development of alumina- ceria ceramic composite cutting tool", International Journal of Refractory Metals \&Hard Materials, vol. 22, no 1, pp. 17-20, January 2004.

[15] A. Senthil Kumar, A. Raja Durai, T. Sornakumar, "Machinability of hardened steel using alumina based ceramic cutting tools", International Journal of Refractory Metals \&Hard Materials, vol. 21, no 3-4, pp. 109-117, MayJuly 2003.

[16] C. Piconi, S. G. Condo and T. Kosmac, "Alumina- and zirconia-based ceramics for load-bearing applications", Advanced Ceramics for Dentistry, chapter 11, pp. 219-253, September 2013.

[17] R. Stevens, Zirconia and Zirconia Ceramics, Magnesium Elektron Ltd, Manchester, U.K., 1986.

[18] C. W. Kuo, Y. H. Shen, F. L. Yen, H. Z. Cheng, I. M. Hung, S. B. Wen, et al., "Phase transformation behavior of 3 mol\% yttria partially-stabilized $\mathrm{ZrO} 2$ (3Y-PSZ) precursor powder by anisothermal method", Ceramics International, vol. 40, no 2, pp. 3243-3251, March 2014.

[19] O. Vasylkiv, Y. Sakka and V. V. Skorokhod, "Hardness and Fracture toughness of alumina-doped tetragonal zirconia with different yttria contents", Materials Transactions, vol. 44, no 10, pp. 2235-2238, October 2003.

[20] S. Ramesh, S. Meenaloshini, C. Y. Tan, W. J. K. Chew and W. D. Teng, "Effect of manganese oxide on the sintered properties and low temperature degradation of Y-TZP ceramics", Ceramics International, vol 34, no 7, pp. 16031608, September 2008.

[21] Y. Sakka, T. Ishii, T. S. Suzuki, K. Morita and K. Hiraga, "Fabrication of high-strain rate superplastic ytrriadoped zirconia polycrystals by adding manganese and aluminum oxides", Journal of the European Ceramic Society, vol. 24, no 2, pp. 449-453, July 2003.

[22] H. Zhou, J. Li and D. Yi, Xiao L, "Effect of manganese oxide on the sintered properties of 8YSZ", Physics Procedia, vol. 22, pp. 14-19, December 2011. 